\title{
Extraction Methods and Technological Means of Drying Maggots (Musca domestica) for Good Nutritional Quality
}

\section{Isidore Noudéhoungbèa Odjo ${ }^{1 *}$, Gaston Antoine Djihinto ${ }^{4}$, Chimène Agrippine Rodogune Yelouassi², Arnauld Sèdjro Martin Djissou ${ }^{1}$, Bernard Adjakossa ${ }^{1}$, Pierre Dossou-Yovo ${ }^{2}$, Guy Apolinaire Mensah ${ }^{3}$, Emile Didier Fiogbe ${ }^{1}$}

\section{${ }^{1}$ Laboratory of Research on Wet Lands, LRZH, FAST, University of Abomey-Calavi, Benin; ${ }^{2}$ Laboratoire de Recherche en Traitement et Conservation des Produits Halieutiques; ${ }^{3}$ Institut National des Recherches Agricoles du Bénin (INRAB); ${ }^{4}$ Direction de la production balieutique, Benin, West Africa.}

\begin{abstract}
In order to make maggot meal (Musca domestica) available for use in fish feed, a production experiment was conducted to determine the easy harvesting method to maximize maggot production density by surface unit with appropriate technological means for their drying. For example, the simple sifter (MTS), hot water (MEC), single water (MES), hot water sifter (MTEC) and single water sifter (MTES) methods were tested in triplicate for the harvest of maggots from the same type of production substrate (2:1 ratio of viscera and soy cake) and four technological means (sun drying sifter, improved sun drying device, freeze-dryer and electric oven) used to dry the maggots harvested. The results showed that in addition to the harvesting time, which varies according to the harvesting method, there is a significant difference $(\mathrm{P}<0.05)$ for the density of production of maggots by unit area with the best density obtained with the sifter method - hot water (MTEC, $833.33 \mathrm{~g} . \mathrm{m}^{-2}$ ). The drying of the maggots in the freeze dryer and in the improved sun drying device allowed a better preservation of the physical appearance of the maggots with a better biochemical composition, especially in crude proteins $(\mathrm{P}>0.05)$. From this experiment, the best method of harvesting maggots is that using the sifter associated with hot water and the improved sun drying device is the effective technological means of drying maggots because it allows for a good content in protein and does not require energy cost.
\end{abstract}

Keywords: Maggot, Harvesting method, Drying technology, Biochemical composition, Energy cost.

Editor | Muhammad Nauman Zahid, Quality Operations Laboratory, University of Veterinary and Animal Sciences, Lahore, Pakistan.

Received | February 07, 2019 Accepted | February 22, 2019; Published | April 01, 2019

*Correspondence | Isidore Noudehoungbea Odjo, Laboratory of Research on Wet Lands, LRZH, FAST, University of Abomey-Calavi, Benin, West Africa; Email: odjoisidore@gmail.com

Citation | Odjo IN, Djihinto GA, Yelouassi CAR, Djissou ASM, Adjakossa B, Dossou-Yovo P, Mensah GA, Fiogbe ED (2019). Extraction methods and technological means of drying maggots (musca domestica) for good nutritional quality. S. Asian J. Life Sci. 7(1): 14-18.

DOI | http://dx.doi.org/10.17582/journal.sajls/2019/7.1.14.18

ISSN | 2311-0589

Copyright $(0) 2019$ Odjo et al. This is an open access article distributed under the Creative Commons Attribution License, which permits unrestricted use, distribution, and reproduction in any medium, provided the original work is properly cited.

\section{INTRODUCTION}

$\mathrm{F}$ ood self-sufficiency in animal protein is nowadays a challenge for Benin's economic development. Fish products play a very important role in human nutrition. They constitute the most important source of animal protein in the diet of the Beninese population and represent $31.9 \%$ of the proteins of animal origin then $5.5 \%$ of the total proteins (FAO, 2016). In Benin, the supply of fishery resources is proving difficult on an ongoing basis because of overfishing, which is leading to a considerable reduction in fish stocks. Despite this, some of these resources are used for the production of farmed food. This is the case of flour and fish oil considered as good food for fish. It is therefore imperative to promote fish farming in its diversification in order to reduce, on the one hand, the import of frozen fish 
and to reduce the fishing pressure that threatens the survival of several fish species on the other hand. But this fish farm is facing the problem of food because of the use of fishmeal as the main source of protein in the fish diet. It is therefore necessary to find alternative and available sources of protein capable of meeting the nutritional needs of fish. In the past, flour and fish oil have been used largely as main ingredients in aquaculture. These less and less used ingredients (Hardy, 2010; Oliva-Teles et al., 2015) have fluctuated in availability and cost. Today, their use is increasingly reduced to cover the amino acid and other nutrient content of fish for growth and meat quality.

Increasingly, aquaculture feed manufacturing industries are using alternative sources (nutritious wealth, availability and reduced costs) for fishmeal (Gatlin et al., 2007; Naylor et al., 2009). Among these alternative sources, animal proteins appear as potential candidates with excellent nutritional qualities (Djissou, 2017). They contain high levels of protein and lipids that make them even more interesting in the formulation of profitable foods in aquaculture. Sources of animal protein including insects such as locusts, termites, maggots, earthworms, etc. have been used in fish feed (Krogdahl et al., 2010; Desai et al., 2012; Djissou et al., 2016; Djissou, 2017).

Maggots (Musca domestica), short cycle and easy to produce, are rich in nutrients including protein (Ogunji et al., 2008; Aniebo et al., 2008) offering real potential for partial or total replacement of fishmeal (Djissou et al., 2015; Odjo et al., 2018). Their nutrient richness of fly larvae (maggots), their high digestibility (> 90\%) and low levels of antinutritional factors have been proven in fish feed (Djissou et al., 2016). Otherwise, the production of maggots from organic waste and / or household waste contributes to sanitation and environmental management.

To make maggots available for fish feed, continuous production is required based on criteria such as production density by unit area, harvesting methods and technological means of drying. All this to make profitable the production in order to pass on the industrial scale. The objective of this study was to present, after the production of maggots, methods to maximizing their harvest and the different technological means of drying them.

\section{MATERIALS AND METHODS}

\section{Experimental Production Design}

The production of larvae (maggots) of houseflies (Musca domestica) was conducted on the fish diversification station of the Laboratory for Research on Wetlands of the University of Abomey-Calavi.

The maggots used were produced at the (LRZH) station from a combination of substrate (2: 1 ratio) of chicken viscera and soy cakes (Djissou et al., 2015, Odjo et al., 2018). $3 \mathrm{~kg}$ of this combination were seeded in circular plastics, surface $0.5 \mathrm{~m}-2$ each, and placed in a box away from sunlight, rain and predators (lizards, birds, rats etc.) at an average temperature of $30^{\circ} \mathrm{C}$ with a relative humidity of $92 \%$. The maggots produced were obtained and dried according to different harvesting methods and means of drying.

\section{Harvesting Methods}

For the maggots harvest, different methods were used: simple sifter method (MTS), simple water method (MES), hot water method at $15^{\circ} \mathrm{C}$ (MEC), method of the simple sifter-water association (MTES), method of the association sifter-hot water (MTEC). For each method, a container is used to collect the collected maggots.

\section{DRYING}

The drying of the maggots harvested was carried out according to four (04) different technological means namely: an improved device of drying in the sun1 which is solid wood with stainless wire mesh being able to turn on trestles (Dossou-Yovo et al., 2010), a sifter sun drying2 consists of a frame made with wooden battens, a lyophilizer3 that allows a cold drying (at low temperature and vacuum) and electric oven 4 that allows to dry

\section{Bromatological Analysis}

The biochemical analyzes (proteins, dry matter, ash) were carried out in duplicate according to the standard methods of AOAC (1990) and concerned the maggot meal resulting from the different technological means of drying.

Crude proteins $(\% \mathrm{~N} \times 6.25)$ were assayed by the kjeldahl method. The lipids were determined by the Soxhlet hot method, the dry matter by weight loss measurement after drying for 24 hours in an oven at $105^{\circ} \mathrm{C}$. Ashes were determined after burning the samples in the oven at $550^{\circ} \mathrm{C}$ for 24 hours.

\section{Statistical Analysis}

The resulting data were subjected to a one-way analysis of variance after verification of homogeneity and normality using Statviews statistical software (version 5.01). If there is a significant difference, Fisher's LSD test was used to compare two to two of the averages, the significance level being set at $5 \%$.

\section{RESULTS}

Table 1 shows the duration and density of production of maggots by unit area according to harvesting methods. The maggot harvesting time did not vary significantly from one method to another $(\mathrm{P}>0.05)$ except when using the simple 
Table 1: Time and density production by unit area of maggots according to harvesting methods

\begin{tabular}{llllll} 
& MTS & MEC & MES & MTEC & MTES \\
Harvesting time $(\mathrm{min})$ & $27 \pm 1^{\mathrm{a}}$ & $18 \pm 2^{\mathrm{b}}$ & $20 \pm 2^{\mathrm{b}}$ & $15 \pm 3^{\mathrm{b}}$ & $23 \pm 2^{2 \mathrm{~b}}$ \\
\hline Density Production $\left(\mathrm{g} \cdot \mathrm{m}^{-2}\right)$ & $533 \pm 91^{\mathrm{a}}$ & $562 \pm 70^{\mathrm{a}}$ & $391.11 \pm 69^{\mathrm{b}}$ & $833.33 \pm 121^{\mathrm{c}}$ & $498 \pm 26^{\mathrm{a}}$
\end{tabular}

Table 2: Technological means for drying maggots

\begin{tabular}{|c|c|c|c|c|c|}
\hline Means of drying & $\begin{array}{l}\text { Mean temperature } \\
\left({ }^{\circ} \mathrm{C}\right)\end{array}$ & $\begin{array}{l}\text { Duration } \\
\text { (day) }\end{array}$ & $\begin{array}{l}\text { Physical aspect (color } \\
\text { and texture) }\end{array}$ & Energycost & $\begin{array}{l}\text { Accessibility with } \\
\text { producers }\end{array}$ \\
\hline $\begin{array}{l}\text { Improved device of } \\
\text { drying }\end{array}$ & 30 & 4 & Slightlydegraded & Without & Accessible \\
\hline Sifter sun & 30 & $3-4$ & Degraded & Without & More accessible \\
\hline Lyophilizer & 7 & 2 & Normal & Mean & Not very accessible \\
\hline Electric oven & 40 & 1 & Stronglydegraded & Mean & Not very accessible \\
\hline
\end{tabular}

Table 3: Biochimical composition of the Maggots according to the drying technique

\begin{tabular}{lllll} 
Centesimal composition & Proteins & Lipids & Ash & Dry matter \\
\hline Improved device of drying & $49.6 \pm 0.8^{\mathrm{a}}$ & $11.76 \pm 0.84^{\mathrm{a}}$ & $8.67 \pm 0.5^{\mathrm{a}}$ & $86.12 \pm 1.33^{\mathrm{a}}$ \\
\hline Sifter sun & $47.2 \pm 1.6^{\mathrm{a}}$ & $10.88 \pm 1.27^{\mathrm{a}}$ & $8.16 \pm 0.7^{\mathrm{a}}$ & $87.58 \pm 0.73^{\mathrm{a}}$ \\
Lyophilizer & $54.6 \pm 0.2^{\mathrm{b}}$ & $15 \pm 0.71^{\mathrm{b}}$ & $8 \pm 0.66^{\mathrm{a}}$ & $92 \pm 1.71^{\mathrm{a}}$ \\
Electric oven & $41.63 \pm 1.61^{\mathrm{c}}$ & $15.26 \pm 1.1^{\mathrm{b}}$ & $9.38 \pm 0.97^{\mathrm{a}}$ & $89.28 \pm 2.39^{\mathrm{a}}$
\end{tabular}

sieve method. When hot water is used in the harvesting method (MEC, MTEC), the harvest time (15-18 minutes) is relatively short unlike the other methods (20-27 minutes) for MTS, MES and MTES. The same trend is observed for the density of production by unit area where the average production densities obtained are higher at the MEC and MTEC using hot water. This density of production by unit area varies significantly from one method to another $(\mathrm{P}<0.05)$ with the sieve-hot water $(\mathrm{MTEC})$ method that led to the highest density (833.33 g.m-2).

With regard to the technological means used for drying maggots (Table 2), the average temperature and the drying time varies from one technological means to another. These parameters, including temperature, have many consequences on the physical appearance (color and texture) of dried maggots where it is found that the higher the temperature, the more the physical appearance of the maggots is degraded. The drying cost varies according to the type of energy used (expensive for electrical energy) and therefore determines the accessibility of the technological means of drying to the producers.

The biochemical composition of the maggots according to the drying technique (Table 3) reveals that the quality of the maggot meal (proteins and lipids) varies significantly according to the technological means of drying $(\mathrm{P}<0.05)$. The higher the drying temperature, the lower the quality of the maggot meal.

January-June 2019| Volume 7 | Issue 1 | Page 16

\section{DISCUSSION}

Insect meal is one of the best alternatives to partial or total replacement of fish meal, mainly because of its amino acid content and fatty acid profile quite interesting (Nogales-Mérida et al., 2018). The potential use of insect meal has recently attracted a lot of attention (Barroso et al., 2014; Henry et al., 2015). These insects are true sources of animal protein for fish, especially for continental species (Nyinawamwiza, 2007; Djissou et al., 2017). Increasingly, larvae of maggots (Musca domestica) are used as a partial or total replacement for fishmeal in the diet of tropical freshwater fish (Djissou et al., 2016). The high utilization of maggots in fish feed is due to their relatively easy production, relatively short production cycle (3-5 days) and above all their high nutrient content (Djissou et al., 2018). But their permanent availability and their nutritional quality conditions their use for obtaining good zootechnical performances.

For a large scale use of maggots in fish feed, many criteria including the production substrate, the production density by unit area and the production time are highlighted to make them available. The work of several authors has shown the different types of maggot production substrates. Most of these substrates are organic waste (Ajani et al., 2004; Djissou et al., 2015; Kovtunova et al., 2017; Pomalègni et al., 2016), food scraps or restaurant waste (Devic et al, 2018; Xiao et al, 2018). The ability of the flies to attract by the substrates (egg lying) is a function of the color, the texture and especially the odor released by them. 
These characteristics as a function of ecological conditions determine the density of production of maggots that are harvested in different ways. Thus, our work has shown that when produced maggots are harvested by a sieve and hot water, the density of production by unit area is maximized. This is justified on the one hand, by the immobilization of maggots due to hot water (preventing them from sinking further into the substrate) since they are at this stage for most of the surface substrates (geotropism positive) and on the other hand, by the probable opening of the mesh of the sieve which allow more easily and quickly their harvest. Results on the use of insects in the aquaculture of aquaculture species were carried out on the types of larvae used, their condition (fresh or dry, whole, defatted, etc.) or their heat treatment (sun drying, electric oven, lyophilizer) by Gasco et al. (2018). The results of our work revealed that the technological means of drying maggots harvested plays an important role in the physical and nutritional quality of dried maggots. These technological means, mainly depending on the temperature and the duration of drying, alter or not the physical quality of the dried product. This alteration or degradation of the product obtained is easily explained because the higher the drying temperature, the more the finished product is affected (degraded). Indeed, as the drying temperature increases, maggots undergo a biological alteration to their physical appearance (Djissou, 2017). This assertion is confirmed by the results of our work where freeze dryer drying (cold drying, $7^{\circ} \mathrm{C}$ ) allowed the conservation of the physical appearance of the maggot (color, texture) unlike the electric oven $\left(40^{\circ} \mathrm{C}\right)$ with a strongly degraded appearance. But these two means of drying require an energy cost unlike those using the sun as a source of energy with a slightly degraded aspect of the dried product at the level of the improved drying device.

Moreover, the biochemical composition of dried maggots varies greatly depending on the technological means used in particular for their protein and crude lipid contents. Freeze Dried Cypress and Enhanced Dryer have a high protein content compared to the others with the lowest content achieved with electric oven dried maggots. This indicates that the protein content of dried maggots decreases with increasing drying temperature. These results confirm the work of Djissou et al. (2017) who asserts that the chemical composition of biological samples are no longer conserved as the drying temperature increases thus denaturing the binding of peptide chains. The improved drying device maggots appears as the technological means of drying does not require energy cost of drying and to have a good nutritional quality of maggots.

Maggots that are sources of animal protein are high in protein with a good content of essential amino acids (Gasco et al., 2018). Its richness in vitamins including group $A$ and its content in growth factor make it, besides the absence of cellulosic compounds and antinutritional factors, an excellent substitute for fishmeal in animal feed, especially fish. But the risk of bacterial contamination often arises for animal protein sources, hence the need to find an effective means of preservation in order to prolong its duration for effective use on the one hand, and to maintain its nutritional quality on the other hand share.

\section{ACKNOWLEDGEMENTS}

The authors thank_the director of Laboratory of Research on Wet Land for having accepted us on his site, Mr Salvain KOUGBLENOU for the analyses.

\section{CONFLICT OF INTEREST}

There is no conflict of interest.

\section{AUTHORS CONTRIBUTION}

All authors, Isidore Noudéhoungbèa Odjo, Gaston Antoine Djihinto, Chimène Agrippine Rodogune Yelouassi, Arnauld Sèdjro Martin Djissou, Bernard Adjakossa, Pierre Dossou-Yovo, Guy Apolinaire Mensah and Emile Didier Fiogbe have made adequate effort on all parts of the work necessary for the development of this manuscript according to his expertise. All authors read and approved the final manuscript.

\section{RÉFÉRENCES}

- Ajani EK, Nwanna LC, Musa BO (2004). Replacement of fishmealwith maggot meal in the diets of Nile tilapia, Oreochromis niloticus. World Aquacult. 35: 52-54.

- Aniebo AO, Erondu ES, Owen OJ (2008). Proximate composition of house fly larvae (Musca domestica) meal generated from mixture of cattle blood and wheat bran. Livest. Res. Rural Develop. 20(12): 1-5. Retrieved 12/10/2008, from http://www.lrrd.org//rrd20/12/ anie20205.htm

- AOAC (1990). Official Methods of Analysis of the Association of Official Analytical Chemists, 15th Ed. Association of Official Analytical Chemists, Arlington, VA, USA. Retrieved from http:law.resource.org/pub/us/cfr/ibr/002/ aoac.methods.1.1990.pdf

- Barroso FG, de Haro C, Sanchez-Muros MJ, Venegas E, Martínez-Sánchez A, Pérez-Bañón C (2014). The potential of various insect species for use as food for fish. Aquacult. 422-423:193-201. https://doi.org/10.1016/j. aquaculture.2013.12.024

- Desai AR, Links MG, Collins SA, Mansfield GS, Drew MD, Van Kessel AG, Hill JE (2012). Effects of plantbased diets on the distal gut microbiome of rainbow trout (Oncorhynchusmykiss).Aquacult. 350353: 134142. https:// doi.org/10.1016/j.aquaculture.2012.04.005

- Devic E, Leschen W, Murray F, Little DC (2018). Growth performance,feed utilization and body composition of 
advancednursing Nile tilapia (Oreochromis niloticus) fed diets containingblack soldier fly (Hermetia illucens) larvae meal. Aquacult. Nutr. 24: 416-423.

- Djissou ASM (2017). Bases biochimiques de fabrication d'aliments sans farine de poisson pour la production marchande de Clarias gariepinus (Burchell, 1822) et Oreochromis niloticus (1758). Thèse de Doctorat. Ecole Doctorale des Sciences de la Vie et de la Terre, Université d'Abomey-Calavi. 189p.

- Djissou ASM, Adjahouinou CD, Koshio S, Fiogbe ED (2016). Complete replacement of fish meal by other animal protein sources on growth performance of Clarias gariepinus fingerlings. Int. Aquat. Res. 8 (4): 333-341. https://doi. org/10.1007/s40071-016-0146-x.

- Djissou ASM, Ochiai A, Koshio S, Fiogbe ED (2017). Effect of total replacement of fishmeal by earthworm and Azolla filiculoides meals in the diets of Nile tilapia Oreochromis niloticus (Linnaeus, 1758) reared in concrete tanks. Indian J. Fish. 64(1): 31-36. https://doi.org/10.21077/ ijf.2017.64.1.55317-05

- DjissouASM, Odjo I, Godome T, Koshio S, Fiogbe ED (2018). Amino Acids Composition of Maggot, Earthworm, Termite and Chicken Viscera Meals Used as Proteins Sources in Fish Feeding. Int. J. Aquacult. 8(2): 114-118. https://doi. org/10.5376/ija.2018.08.0002

- Djissou ASM, Tossavi EC, Vodounnou JD, Toguyeni A, Fiogbé ED (2015). Valorization of agro-alimentary waste for a production of maggots like source of proteins in the animal feeds. Int. J. Agronom. Agricult. Res. 7 (6):42-46.

- Dossou-Yovo P, Bokossa I, Ahouandjinou H, Zolotokopovas, Alaguina I (2010). Performance d'un dispositif amélioré de séchage de poisson fermenté appelé lanhouin au Bénin. Int. J. Biol. Chem. Sci. 4(6): 2272-2279. http://indexmedicus. afro.who.int

- FAO (2016). The state of world fisheries and aquaculture 2016. Contributing to food security and nutrition for all. Food and Agriculture Organization of the United Nations (FAO), Rome.

- Gasco L, Gai F, Maricchiolo G, Genovese L, Ragonese S, Bottari T, Caruso G (2018). Feeds for the aquaculture sector (Current situation and alternative sources). Springerbriefs in molecular science. Chem. Foods. 1-111.

- Gatlin DM, Barrows FT, Brown P, Dabrowski K, Gaylord TG, Hardy RW, Herman E, Hu GS,Krogdahl A, Nelson R, Overturf K, Rust M, Sealey W, Skonberg D, Souza EJ, Stone D,Wilson R, Wurtele E (2007). Expanding the utilization of sustainable plant products inaquafeeds: a review. Aquacult. Res. 38(6): 551-579. https://doi.org/10.1111/j.13652109.2007.01704.x

- Hardy RW (2010). Utilization of plant proteins in fish diets: effects of global demand and suppliesof fishmeal. Aquacult. Res. 41(5): 770-776. https://doi.org/10.1111/j.13652109.2009.02349.x

- Henry M, Gasco L, Piccolo G, Fountoulaki E (2015). Review on the use of insects in the diet offarmed fish: past and future. Anim. Feed Sci. Technol. 203:1-22. https://doi. org/10.1016/j. anifeedsci.2015.03.001

- Kovtunova A, Drevko Y, Faust E, Bannikova A, Larionova O (2017). Dynamics of amino acid profile of Musca domestica larva during cultivation on substrate enriched with microelements. Proceedings of the National Academy of Sciences, India Section B: Biolog. Sci. 1-8. https://doi. org/10.1007/s40011-017-0866-8.

- Krogdahl A, Penn M, Thorsen J, Refstie S, Bakke AM (2010). Important antinutrients in plantfeedstuffs for aquaculture: an update on recent findings regarding responses in salmonids. Aquacult. Res. 41(3): 333-344. https://doi.org/10.1111/ j.1365-2109.2009.02426.x

- Naylor RL, Hardy RW, Bureau DP, Chiu A, Elliott M, Farrell AP, Forster I, Gatlin DM, Goldburg RJ, Hua K, Nichols PD (2009). Feeding aquaculture in an era of finite resources. Proc. Natl. Acad. Sci. 106(36): 15103-15110. https://doi. org/10.1073/pnas.0905235106

- Nogales-Merida S, Gobbi P, Jozefiak D, Mazurkiewicz J, Dudek K,Rawski M, Kieronczyk B, Jozefiak A (2018). Insect meals in fish nutrition. Rev. Aquacult. 1-24. https:// doi.org/10.1111/raq.12281

- Nyinawamwiza L (2007). Valorisation de sous-produits agroindustriels dans l'élevage du poisson-chat africain Clarias gariepinus au Rwanda : influence sur les performances de croissance et de reproduction. Thèse de Doctorat. Facultés Universitaires Notre-Dame de la Paix (FUNDP-Namur), $172 \mathrm{p}$.

- Odjo IN, Djissou ASM, Guézo C, Fiogbé ED (2018). Optimization of maggot production from a mixture of chicken viscera and soya cake based on different ratios. Int. J. Biol. Chem. Sci. 12(4): 1583-1589. https://dx.doi. org/10.4314/ijbcs.v12i4.6

- Ogunji JO, SummanToor RUA, Schulz C, Kloas W (2008). Growth performance, nutrientutilization of Nile tilapia Oreochromis niloticus fed housefly maggot meal (magmeal) diets. Turk. J. Fish Aquat. Sci. 8:141-147.

- Oliva-Teles A, Enes P, Peres H (2015). Replacing fishmeal and fish oil in industrial aquafeeds forcarnivorous fish. In: Davis DA (ed) Feed and feeding practice in aquaculture. Woodhead Publishing, Cambridge. Pp 203-233.

- Pomalégni SCB, Gbemavo DSJC, Kpadé CP, Babatoundé $\mathrm{S}$, Chrysostome CAAM, Koudandé OD, Kenis M, Glèlè Kakaï RL, Mensah GA (2016). Perceptions et facteurs déterminant l'utilisation des asticots dans l'alimentation despoulets locaux (Gallus gallus) au Bénin. J. Appl. Biosci. 98: $9330-9343$.

- Xiao X, Jin P, Zheng L, Cai M, Yu Z, Yu J (2018). Effects ofblack soldier fly (Hermetia illucens) larvae meal protein as a fishmeal replacement on the growth and immune index ofyellow catfish (Pelteobagrus fulvidraco). Aquacult. Res. 49: 1569-1577. 